\title{
Relationships of Biomass-Burning Aerosols to Ice in Orographic Wave Clouds
}

\author{
Cynthia H. Twohy, ${ }^{*}$ Paul J. DeMott, ${ }^{+}$Kerri A. Pratt, ${ }^{\#}$ R. Subramanian, ${ }^{@}$

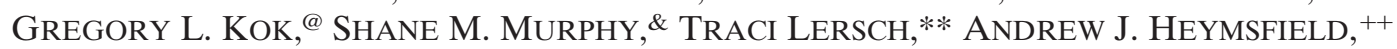 \\ ZhIEN WANG,\# KIM A. PrATHER, " AND JOHN H. SEINFELD\& \\ * Oregon State University, Corvallis, Oregon \\ ${ }^{+}$Colorado State University, Fort Collins, Colorado \\ \# University of San Diego, La Jolla, California \\ ${ }^{\circledR}$ Droplet Measurement Technologies, Boulder, Colorado \\ \& California Institute of Technology, Pasadena, California \\ ** RJ Lee Group, Monroeville, Pennsylvania \\ ${ }^{++}$National Center for Atmospheric Research, Boulder, Colorado \\ \#\# University of Wyoming, Laramie, Wyoming
}

(Manuscript received 8 September 2009, in final form 16 March 2010)

\begin{abstract}
Ice concentrations in orographic wave clouds at temperatures between $-24^{\circ}$ and $-29^{\circ} \mathrm{C}$ were shown to be related to aerosol characteristics in nearby clear air during five research flights over the Rocky Mountains. When clouds with influence from colder temperatures were excluded from the dataset, mean ice nuclei and cloud ice number concentrations were very low, on the order of $1-5 \mathrm{~L}^{-1}$. In this environment, ice number concentrations were found to be significantly correlated with the number concentration of larger particles, those larger than both 0.1 - and $0.5-\mu \mathrm{m}$ diameter. A variety of complementary techniques was used to measure aerosol size distributions and chemical composition. Strong correlations were also observed between ice concentrations and the number concentrations of soot and biomass-burning aerosols. Ice nuclei concentrations directly measured in biomass-burning plumes were the highest detected during the project. Taken together, this evidence indicates a potential role for biomass-burning aerosols in ice formation, particularly in regions with relatively low concentrations of other ice nucleating aerosols.
\end{abstract}

\section{Introduction}

The formation of ice in clouds is still a relatively poorly understood process. Ice nucleation occurs in two primary ways: through homogeneous freezing of liquid solution droplets and through heterogeneous freezing by a particulate nucleus. Homogeneous nucleation, or freezing, occurs at temperatures $T$ colder than about $-37^{\circ} \mathrm{C}$, while heterogeneous freezing can occur at temperatures as warm as $-5^{\circ} \mathrm{C}$ (Mossop 1976). For both these processes, nucleating efficiency varies with temperature and supersaturation with respect to ice (Myers et al. 1992). Under specialized conditions, ice may also be formed by secondary processes such as rime splintering (Hallett and Mossop 1974).

Corresponding author address: Cynthia Twohy, College of Oceanic and Atmospheric Sciences, Oregon State University, Corvallis, OR 97128.

E-mail: twohy@coas.oregonstate.edu
Homogeneous freezing of water droplets can be predicted by classical theory (Heymsfield and Miloshevich 1995; Tabazadeh et al. 1997) whereas heterogeneous ice nucleation is much more complex. There are several mechanisms by which a heterogeneous ice nucleus may initiate ice formation (Cantrell and Heymsfield 2005). These include immersion and condensation freezing, where the ice nucleus is initially present within a cloud droplet, and deposition or contact nucleation (Cooper 1974), where immersion within the liquid phase is not required. Modeling studies have shown that the type and quantity of atmospheric aerosol particles acting as ice nuclei (IN) influence ice cloud microphysical and radiative properties (Jensen et al. 2001; Gierens 2003; Haag and Kärcher 2004).

Particles acting as ice nuclei under various conditions are beginning to be better characterized through both detailed laboratory studies and improved atmospheric measurements. Soil dust is known to be a good heterogeneous ice nucleus (Isono et al. 1959; Sassen et al. 2003; 
Field et al. 2006), and some biological particles such as decaying vegetation and bacteria seem to also be involved in ice formation (Schnell and Vali 1972; Möhler et al. 2007; Bowers et al. 2009). Industrial metals may also play a role (Chen et al. 1998; Twohy and Poellot 2005; Cziczo et al. 2009).

Ice clouds are important in regulating climate (Ramanathan and Collins 1991), in producing precipitation, and in providing sites for chemical reactions. Changes to particulate loadings by anthropogenic activity, whether direct emissions or through land use and precipitation changes, could influence the characteristics of ice and mixed-phase clouds. However, these changes cannot be accurately predicted until we understand the physics of ice formation and the types of particles that initiate it. The work presented here uses a comprehensive in situ dataset to examine the relationships between aerosol chemical and physical characteristics and the ice crystals that we argue must result from primary heterogeneous ice formation.

\section{Experiment}

The Ice in Clouds Experiment-Layer Clouds (ICE-L) was a field investigation of ice formation processes, focusing on primary heterogeneous nucleation. The fall campaign was conducted along the Rocky Mountain range of the United States, where lenticular wave clouds driven by orography are common. The thermodynamic and kinematic environments of lenticular wave clouds are relatively simple and steady, so repeated sampling of the same cloud was possible without substantial temporal changes in cloud characteristics. Wave clouds provide a range of temperature, humidity, and vertical wind conditions in which first ice is expected to form through primary (heterogeneous or homogeneous freezing) processes. In wave clouds the conditions necessary for known secondary ice formation processes like rime splintering (Hallett and Mossop 1974), crystal-to-crystal collision (Vardiman 1978), and fragmentation during sublimation of dendrites (Oraltay and Hallett 1989) are minimized and there is little evidence that such processes occur in these clouds (Cooper and Vali 1981).

Baker and Lawson (2006) summarized the microphysics of wave clouds sampled in this area. They found that in general droplets grow rapidly (within a few hundred meters) in the upwind portion of the wave and then remain relatively monodispersed until they evaporate approximately midway through the cloud. Detectable ice crystals are typically observed mixed with the liquid water portion within a few kilometers downwind from the cloud's leading edge (Cooper and Vali 1981). ICE-L flight tracks included sampling of the clear air upstream of the cloud in a crosswind bow-tie pattern, after which horizontal legs at
TABLE 1. Flights and time periods encompassing the data that passed selection criteria. Note that all data within these time periods were not necessarily used; only those subperiods that passed the criteria given in the text (for reference, see actual cloud data in Fig. 1.)

\begin{tabular}{ccc}
\hline \hline Date & Flight No. & Time (UTC) \\
\hline 7 Nov 2007 & 1 & $1927: 40-2050: 00$ \\
16 Nov 2007 & 3 & $1738: 40-1845: 00$ \\
18 Nov 2007 & 4 & $1858: 20-2353: 20$ \\
29 Nov 2007 & 6 & $1830: 00-1900: 30$ \\
16 Dec 2007 & 12 & $1803: 20-1918: 20$ \\
\hline
\end{tabular}

different altitudes along the wind trajectory were flown. Clouds sampled during ICE-L were approximately 5$30 \mathrm{~km}$ across when sampled horizontally.

Wave cloud passes during five flights aboard the National Science Foundation's C-130 research aircraft were subjected to an extensive screening process to evaluate ice concentrations in clouds that were comparable from flight to flight. This included restrictions based on temperature and horizontal isolation from clouds above and below, as described below. Although temperatures as cold as $-38^{\circ} \mathrm{C}$ were encountered by the aircraft, we focus here on a more limited range of temperatures $\left(-24^{\circ}\right.$ to $-29^{\circ} \mathrm{C}$ ). These in-cloud temperatures were selected as ones common to all five flights; they are also warm enough in most cases to limit possible involvement of homogeneously nucleated ice falling from above, as was seen on some flights (Pratt et al. 2009a; P. R. Field et al. 2010, unpublished manuscript). Video from the forward camera and onboard radar and lidar data were also examined to determine the vertical extent of the clouds and sedimentation of ice from colder temperatures above. Using the remote sensing data, clouds that extended to more than $500 \mathrm{~m}$ above the aircraft were excluded from the data presented here. Interestingly, ice sometimes originates from air lofted from the surface (e.g., Rogers and Vali 1987). In the case of flight 6 (29 Nov 2007), this was occasionally observed; clouds showing influence of convective cells below the flight level were also eliminated. Flight dates and time periods encompassing the selected cloud passes are given in Table 1.

Ice size distributions in cloud were measured with a Particle Measuring Systems 2D-C probe modified with faster electronics relative to the standard instrument and with sizing at $25-\mu \mathrm{m}$ resolution up to $1600-\mu \mathrm{m}$ diameter. Because of uncertainties in the depth of field at small particle sizes and possible overlap with larger cloud droplets, number concentrations reported here begin at a minimum size limit of approximately $60-\mu \mathrm{m}$ diameter, where undercounting errors are expected to be less than $10 \%$ (Korolev et al. 1998). Breakup on instrument surfaces upstream of the sample volume can lead to overcounting, 
but this is expected have no discernable effect on $2 \mathrm{D}-\mathrm{C}$ number concentrations unless crystals exceed $600 \mu \mathrm{m}$ in size (Korolev and Isaac 2005), which rarely occurred during ICE-L (mean crystal diameters for the time periods used ranged from 75 to $575 \mu \mathrm{m}$ ). Finally, some real ice crystals may have been not detected by the $2 \mathrm{D}-\mathrm{C}$ because of the minimum threshold size used. In these wave clouds, however, calculations and observations (Cooper and Vali 1981) indicate that heterogeneously nucleated ice particles would reach detectable size within $1-2 \mathrm{~km}$ downstream of the leading cloud edge, which is only about $1 / 10$ of the horizontal distance typically sampled in cloud. Additionally, our temperature and remote sensing screening eliminates possible influence of small ice from homogeneous freezing regions above. Therefore the mean ice crystal concentrations reported here can be assumed to be accurate within $\sim 20 \%$.

Equivalent potential temperature $\theta_{e}$ is conserved for saturated adiabatic processes (Wallace and Hobbs 1977) and should be nearly constant as an air parcel moves from upwind of a wave cloud through it along individual streamlines (note that the aircraft itself samples across streamlines). Therefore, mean in-cloud $\theta_{e}$ values were used to identify clear-air periods that were characteristic of air feeding the clouds of interest. Flights with large variations in observed $\theta_{e}$ were reexamined; in some cases, in particular if aerosol characteristics were found to be variable with $\theta_{e}$, cloud data periods were regrouped into fewer passes with more uniform $\theta_{e}$ characteristics. Number concentrations for both cloud and aerosol parameters are reported in terms of ambient pressure and temperature conditions.

Clear air was defined to occur when concentrations from the 2D-C probe were equal to 0.0 and concentrations from Droplet Measurement Technologies' cloud droplet probe (CDP), which measures particles or droplets $2-50 \mu \mathrm{m}$ in diameter, were less than $0.1 \mathrm{~cm}^{-3}$. Clearair $\theta_{e}$ values were also limited to those within $1.5^{\circ}$ above or below the mean of the corresponding cloud periods, as discussed above. While a more stringent $\theta_{e}$ criterion would have been desirable, this would have greatly limited data from some of the instruments. For some flights, clear-air data were sparse, in particular those days with extensive cloud such as flight 3 . Aerosol data were matched as closely as possible to the times of the actual cloud passes in each period. However, some of the aerosol data were not always available immediately upstream of the cloud passes and had to be averaged over longer or different time segments (but still within the $3^{\circ}$ $\theta_{e}$ range) to obtain meaningful values.

A variety of techniques was used to provide clear-air aerosol information, including size distributions and refractory black carbon and ice nuclei concentrations. Two different types of aerosol mass spectrometers [a
Compact Time-of-Flight Aerosol Mass Spectrometer (C-ToF-AMS) and an Aircraft Aerosol Time-of-Flight Mass Spectrometer (A-ATOFMS)] as well as electron microscopy were used to provide detailed chemical information. In some cases these instruments were also operated in-cloud behind a counterflow virtual impactor (CVI; Noone et al. 1988). Much of that data is presented elsewhere (Pratt et al. 2009a, 2010a; Eidhammer et al. 2010; DeMott et al. 2010, hereafter DM). The aerosol instruments with appropriate references detailing the techniques are listed in Table 2.

\section{Results and discussion}

\section{a. Ice concentrations}

Figure 1 shows $1-\mathrm{Hz}$ ( $\sim 150-\mathrm{m}$ horizontal average) ice concentrations greater than $0.1 \mathrm{~L}^{-1}$ for the periods meeting all criteria for the five flights studied. While none of the ice concentrations were very high, in a relative sense, flights 1,3 , and 4 had low ice concentrations for all passes within the criteria set here, and flight 12 had higher ice concentrations. Only one wave cloud period for flight 3 matched both the temperature and isolated wave cloud criteria, since most of the clouds sampled that day had complex layered structures with substantial ice sedimentation from above. Ice concentrations in clouds with ice falling from above were often higher by an order of magnitude or more than for isolated clouds at the same altitude.

Flight mean and peak ice concentrations for all accepted 1-Hz in-cloud data (see Fig. 1), regardless of duration, are shown in Fig. 2. Flight 12 had the highest ice concentration (mean of $4.6 \mathrm{~L}^{-1}$ ); flight 4 was an order of magnitude lower (mean of $0.4 \mathrm{~L}^{-1}$ ). From the Scientific Overview Document, the overarching goal of the Ice in Clouds Experiment is "To show that under given conditions, direct ice nucleation measurement(s), or other specific measurable characteristics of the aerosol, can be used to predict the number of ice particles forming by nucleation mechanisms in selected clouds" (available online at http://www.eol.ucar.edu/projects/ice-1/). To help achieve this, differences in aerosol characteristics on the five different days are examined in the next section. While ice nuclei are, of course, highly specialized and constitute a very small segment of the total aerosol number, it is expected that ice nuclei populations are enhanced in conjunction with certain types of aerosol populations that have similar source regions or atmospheric histories.

\section{b. Aerosol number concentration in different size ranges}

A condensation particle counter measured the total concentration of particles larger than about $0.01 \mu \mathrm{m}$ in 
TABLE 2. Instruments used to measure aerosol characteristics.

\begin{tabular}{|c|c|c|c|c|}
\hline Instrument name & Acronym & Manufacturer/operator & Variable measured & Inlet* \\
\hline $\begin{array}{l}\text { Condensation Nucleus } \\
\text { Counter model } 3760 \\
\text { (Twohy 1991) }\end{array}$ & $\mathrm{CNC}$ & $\begin{array}{l}\text { Thermo Systems Inc./National } \\
\text { Center for Atmospheric } \\
\text { Research }\end{array}$ & $\begin{array}{l}\text { Total number concentration } \\
\quad>0.01 \mu \mathrm{m} \text { diameter }\end{array}$ & UWyo \\
\hline $\begin{array}{l}\text { Ultra High Sensitivity } \\
\text { Aerosol Spectrometer }\end{array}$ & UHSAS & $\begin{array}{l}\text { Particle Metrics Inc./National } \\
\text { Center for Atmospheric } \\
\text { Research }\end{array}$ & $\begin{array}{c}\text { Size distribution } 0.10- \\
1.0 \mu \mathrm{m} \text { diameter** }\end{array}$ & Wing-mount \\
\hline $\begin{array}{l}\text { Single Particle Soot } \\
\text { Photometer (Schwarz } \\
\text { et al. 2006) }\end{array}$ & SP-2 & $\begin{array}{l}\text { Droplet Measurement } \\
\text { Technologies/Droplet } \\
\text { Measurement Technologies }\end{array}$ & $\begin{array}{l}\text { Refractory black carbon } \\
\text { number and mass }>0.08 \mu \mathrm{m} \\
\text { diameter }\end{array}$ & $\begin{array}{l}\text { Rear-facing } \\
\text { inlet on } \\
\text { bottom of } \\
\text { plane }\end{array}$ \\
\hline $\begin{array}{l}\text { Continuous Flow Diffusion } \\
\text { Chamber (Rogers et al. } \\
\text { 2001) }\end{array}$ & CFDC & $\begin{array}{l}\text { Colorado State University/ } \\
\text { Colorado State University }\end{array}$ & Ice nuclei concentration & UWyo \\
\hline $\begin{array}{l}\text { Aircraft Aerosol Time-of- } \\
\text { Flight Mass Spectrometer } \\
\text { (Pratt et al. 2009b) }\end{array}$ & A-ATOFMS & $\begin{array}{l}\text { UC San Diego/UC San } \\
\text { Diego }\end{array}$ & Single particle composition & UWyo \\
\hline $\begin{array}{l}\text { Compact Time-of-Flight } \\
\text { Aerosol Mass Spectrometer } \\
\text { (Murphy et al. 2009) }\end{array}$ & C-ToF-AMS & Aerodyne/Cal Tech & $\begin{array}{l}\text { Nonrefractory aerosol } \\
\text { composition }\end{array}$ & HIMIL \\
\hline $\begin{array}{l}\text { Scanning Transmission } \\
\text { Electron Microscopy }\end{array}$ & STEM/EDS & $\begin{array}{l}\text { Oregon State University/ } \\
\text { RJ Lee Group }\end{array}$ & $\begin{array}{l}\text { Single particle morphology } \\
\text { and composition }\end{array}$ & $\begin{array}{l}\text { CVI w/o } \\
\text { counterflow }\end{array}$ \\
\hline
\end{tabular}

diameter, while an ultrahigh sensitivity aerosol spectrometer (UHSAS) measured the size distribution of particles with diameters between about 0.10 and $1.0 \mu \mathrm{m}$. DM found that atmospheric ice nuclei concentrations are usually correlated with the number of particles larger than $0.5 \mu \mathrm{m}$ in diameter, so a total concentration using this subset of the UHSAS distribution was also computed.

The relationships between ice concentration and aerosol particle concentrations in these different size categories are shown in Fig. 3. The small mean particle concentrations, ranging from only 94 to $315 \mathrm{~cm}^{-3}$ in sizes $>0.01-\mu \mathrm{m}$ diameter, demonstrate that the midtropospheric air during the ICE-L period was quite clean. For comparison, Hofmann et al. (1998) presented 25-yr mean CN concentrations at $8 \mathrm{~km}$ of about $400 \mathrm{~cm}^{-3}$ during winter and $900 \mathrm{~cm}^{-3}$ during summer over Wyoming. However, aerosol chemical data (discussed below) indicated that intrusions of some particles from industrial activity and biomass burning did occur.

The coefficients of determination $r^{2}$ in Fig. 3 indicate that strong relationships exist between ice concentrations and the number concentration of particles larger than 0.10 and $0.50 \mu \mathrm{m}\left(r^{2}=0.89\right.$ and 0.85 , respectively $)$. Because of the small number of samples, however, a high $r^{2}$ does not necessarily mean the relationships are statistically significant. Table 3 tabulates whether the null hypothesis (that there is no relationship between ice concentration and the aerosol parameter of interest) can be rejected at a probability level $p$ of 0.05 . If so, the relationship is statistically significant. If the null hypothesis is not rejected, a relationship may still exist, but it cannot be proven with this dataset. For the correlations between particles $>0.10 \mu \mathrm{m}$ and particles $>0.50 \mu \mathrm{m}$ versus ice concentration shown in Fig. 3, the null hypothesis can be rejected and both have a statistically significant relationship to ice concentration.

\section{c. Aerosol chemistry}

The chemistry of ambient aerosol particles was measured by several different techniques, including an aircraft aerosol time-of-flight mass spectrometer (Pratt et al. 2009b), an Aerodyne compact time-of-flight aerosol mass spectrometer (Murphy et al. 2009), and scanning transmission electron microscopy and energy dispersive X-ray analysis. Below, we examine information obtained by the different techniques to see if chemical characteristics of the aerosols are significantly correlated with ice concentrations in the ICE-L orographic clouds.

\section{1) Single PARTICLE REFRACTORY BLACK CARBON}

Light-absorbing soot particles are produced from biomass and coal combustion and may contain elemental or black carbon as well as brown and organic carbon 

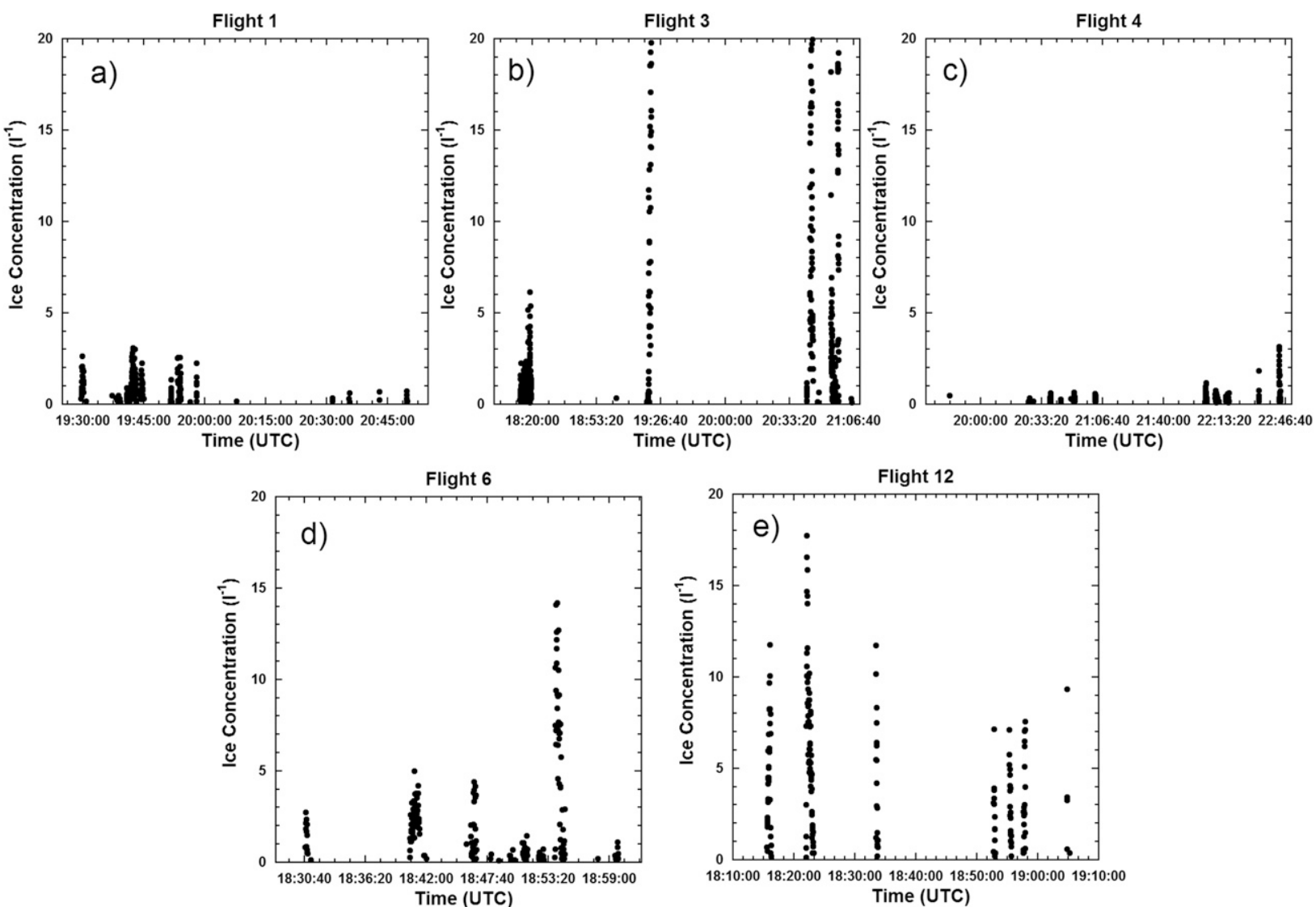

FIG. 1. Ice crystal number concentrations ( $>60 \mu \mathrm{m}$ ) vs time for the selected data periods during flights (a) 1, (b) 3, (c) 4, (d) 6, and (e) 12 . Data points are reported each second (about $150 \mathrm{~m}$ in horizontal distance), with uncertainty in the concentrations estimated at about $20 \%$.

(Andreae and Gelencsér 2006). Here we use the generic term "soot" for general discussion and more specific terms when discussing individual measurements from different instruments that measure specific properties of the particles.

Soot is known to be present in both water drops and ice crystals in the atmosphere (Twohy et al. 1989; Chýlek et al. 1996; Baumgardner et al. 2008; Cozic et al. 2008). Some types of soot particles from combustion have been shown to sometimes act as ice nuclei in the laboratory under condensation or immersion freezing conditions (e.g., DeMott 1990; DeMott et al. 1999; Diehl and Mitra 1998; Dymarska et al. 2006; Gorbunov et al. 2001; Möhler et al. 2005). However, this is not a consistent feature of soot particles, and it is not clear what the controlling factors are (Kärcher et al. 2007). Dymarska et al. (2006) found that soot particles were ineffective ice nuclei under subsaturated conditions with respect to liquid water at temperatures warmer than $-30^{\circ} \mathrm{C}$. Most ICE-L clouds showed little evidence either of deposition nucleationoccurring in ice-supersaturated but liquid water subsaturated regions upstream of the liquid water clouds —or of contact nucleation occurring in evaporating downdraft regions (Durant and Shaw 2005). Therefore, the probable modes of nucleation in these clouds were condensation or immersion freezing in the regions containing liquid water.

For ICE-L, mean number concentrations of refractory black carbon (rBC; Schwarz et al. 2009) from the Single Particle Soot Photometer (SP-2) are compared to ice crystal concentrations in Fig. 4. Both total rBC concentrations [measured mass range is $0.5-10.5$ fg or 0.08 $0.22-\mu \mathrm{m}$ mass-equivalent diameter (MED)] and only rBC particles larger than $0.10-\mu \mathrm{m}$ MED, a size range corresponding with an ice nucleation formulation used in some models (Phillips et al. 2008), are shown. A very high correlation $\left(r^{2}>0.99\right)$ is observed for $\mathrm{rBC}$ in both size ranges; in fact, both are significant not only at a $p$ value of 0.05 (Table 3 ) but also down to probabilities less than 0.0005 . Within the relatively low ice concentration range observed on most ICE-L flights, then, ice concentrations are strongly positively correlated with $\mathrm{rBC}$ concentration in the ambient aerosol for these ICE-L cases. This does not necessarily occur in all environments, however. During dust-storm outbreaks (sometimes mixed 


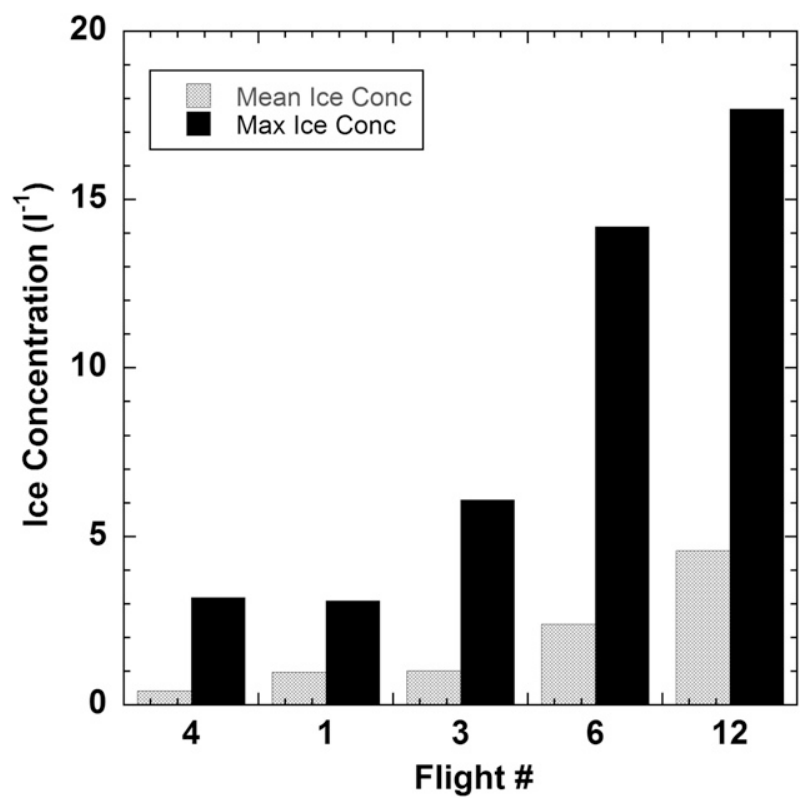

FIG. 2. Mean and maximum ice concentrations for isolated ICE-L clouds during different flights at temperatures of $-24^{\circ}$ to $-29^{\circ} \mathrm{C}$. Uncertainty in the measured concentrations is estimated at about $20 \%$.

with pollution) that can occur downwind of Asia, high ice nuclei concentrations were more strongly related to dust concentrations than to refractory black carbon concentrations (Stith et al. 2009).

\section{2) Single PARTICLE COMPOSITION BY A-ATOFMS}

The A-ATOFMS measured both positive and negative ions associated with individual aerosol particles between about 70- and 1200-nm vacuum aerodynamic diameter, although maximum transmission and scattering efficiency occurs above $200 \mathrm{~nm}$ (Pratt et al. 2009b). Particles sampled from air in the $\theta_{e}$ range described earlier were categorized as crustal dust, biological, salts $(\mathrm{NaKCl})$, biomass burning, organic carbon (OC), elemental carbon (EC), or internal mixtures of OC and EC as detailed in Spencer and Prather (2006). Since the A-ATOFMS detects elemental carbon based on the presence of carbon cluster ions $\left(\mathrm{C}_{n}^{ \pm}\right)$, we use the more correct "elemental carbon" nomenclature in this section, recognizing that it is related to the refractory black carbon measured by incandescence by the SP-2 and to the generic "soot" used elsewhere (Andreae and Gelencsér 2006). Particles containing sulfate and/or nitrate, for which no positive ion mass spectra were collected, are included within the category "sulfate-nitrate only." Biomassburning particles were defined as those with potassium dominating the positive ions, as well as containing organic carbon and elemental carbon, and sulfate (Silva et al.

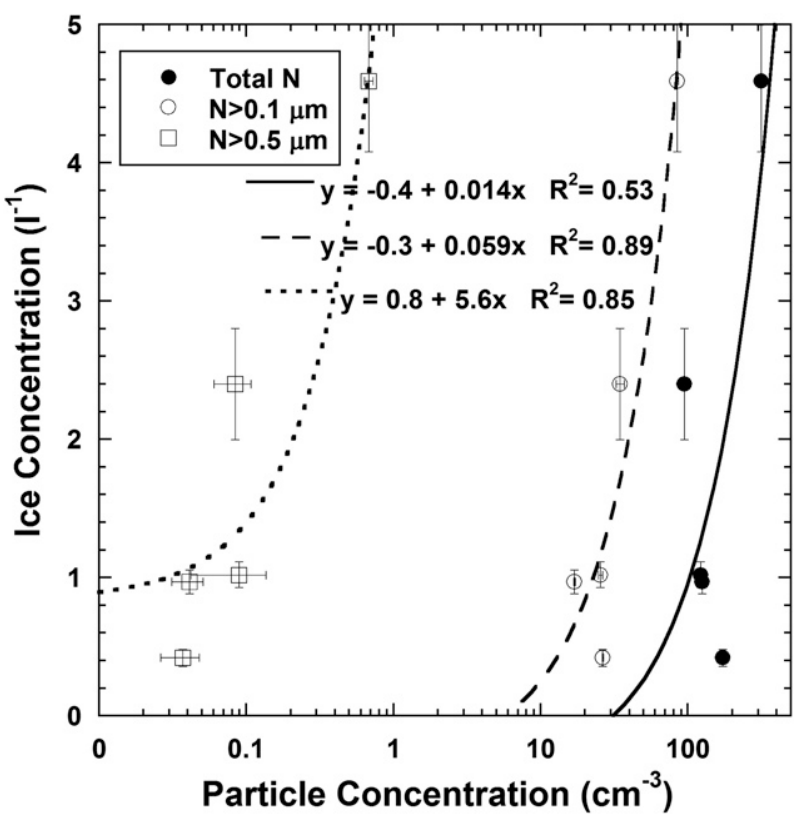

FIG. 3. Relationship between mean aerosol particle concentration and ice crystal concentration in different size ranges for the five flights. Error bars represent a $95 \%$ confidence interval for the sample means $[ \pm($ standard error $\times 1.96)]$. Standard errors for the aerosol means were relatively low for the $\theta_{e}$ ranges used. Uncertainty due to the measurement itself is estimated at $20 \%$ for ice concentration and $10 \%$ for particle concentration.

1999; Reid et al. 2005), and occasional internal mixing with nitrate and ammonium was also observed. While certain particle types were typically externally mixed (e.g., biological particles and biomass-burning particles), it is important to note that these particle type

TABLE 3. Significance of relationships (at probability level $p=$ $0.05)$ between aerosol particle parameters and ice number concentration in clouds.

\begin{tabular}{lcccccc}
\hline \hline \multicolumn{1}{c}{ Parameter } & $r^{2 \mathrm{a}}$ & $r^{\mathrm{b}}$ & $n^{\mathrm{c}}$ & $t_{\text {obs }}^{\mathrm{d}}$ & $t_{\text {crit }}^{\mathrm{e}}$ & Reject? $^{\mathrm{f}}$ \\
\hline Aerosol $>0.01 \mu \mathrm{m}$ & 0.53 & $(+) 0.73$ & 5 & 1.8 & 2.35 & No \\
Aerosol $>0.10 \mu \mathrm{m}$ & 0.89 & $(+) 0.94$ & 5 & 4.9 & 2.35 & Yes \\
Aerosol $>0.50 \mu \mathrm{m}$ & 0.85 & $(+) 0.92$ & 5 & 4.1 & 2.35 & Yes \\
rBC total number & 0.99 & $(+) 1.00$ & 5 & 18 & 2.35 & Yes \\
rBC $>0.10 \mu \mathrm{m}$ & 1.00 & $(+) 1.00$ & 5 & 27 & 2.35 & Yes \\
IN concentration & 0.39 & $(+) 0.62$ & 5 & 1.4 & 2.35 & No \\
\hline
\end{tabular}

a Pearson coefficient of determination from the appropriate figure/ regression.

b Pearson coefficient of correlation. Also denotes sign of relationship (positive or negative).

${ }^{c}$ Number of samples.

${ }^{\mathrm{d}}$ Observed $t$ value, $=r\left[(\mathrm{df}) /\left(1-r^{2}\right)\right]^{0.5} ; \mathrm{df}=$ degrees of freedom $(n-2$ for linear fit).

e Critical $t$ value at $p=0.05$, from statistical tables.

${ }^{\mathrm{f}}$ If $t_{\mathrm{obs}}>t_{\mathrm{crit}}$, null hypothesis may be rejected, where the null hypothesis states that there is no relationship between ice concentration and the parameter of interest. 


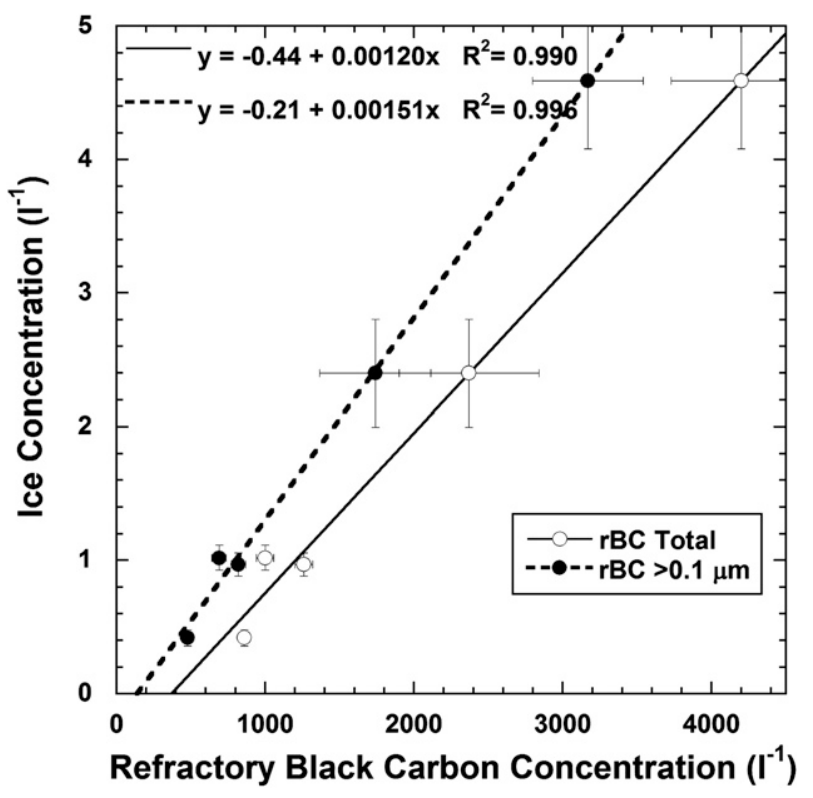

FIG. 4. Relationship between refractory black carbon concentration and ice concentration for ICE-L wave cloud flights. Both total $(>0.08 \mu \mathrm{m})$ and $>0.1-\mu \mathrm{m}$ diameter particles containing $\mathrm{rBC}$ as measured by the SP-2 are shown. Error bars represent a $95 \%$ confidence interval for the sample means [ \pm (standard error $\times$ 1.96)]. Uncertainty in the measurement itself is estimated at $20 \%$ for ice concentration and $10 \%$ for $\mathrm{rBC}$ concentration.

classifications do not reflect all of the chemical components within these particles. For example, EC and ECOC particles were usually internally mixed with some potassium and sulfate. Likewise, organic carbon particles were often mixed with sulfate and sometimes nitrate and ammonium. Since the number of analyzed particles matching the $\theta_{e}$ criteria was small, the following sets of categories were combined in our analysis: dust with biological particles and EC with OC-EC mixed particles. Percentages for each particle type were calculated from the number of particles detected in each category and the total number of particles analyzed within the $\theta_{e}$ criterion. This total ranged from 33 particles for flight 1 to 198 for flight 12 .

Correlations between particle percentage in each of the six categories and ice concentrations were examined, with significance testing given in Table 4 (first six rows of data). No significant relationships were found when percentages only were used. However, ice concentrations would be expected to correlate with the number concentration of preferred nuclei rather than the percent of nuclei relative to other particle types. Therefore, the percentage of particle types in each category was multiplied by the total number of particles $>0.1 \mu \mathrm{m}$ in diameter measured by the UHSAS, which measures a similar size range to the A-ATOFMS. Using this estimate of the number
TABLE 4. Significance of relationships between ATOFMS aerosol chemistry and ice number concentration in clouds. Top rows are percent relative to other categories; bottom rows are percent multiplied by particles larger than $0.10 \mu \mathrm{m}$ as measured by the UHSAS. Column headings are described in Table 3 footnotes.

\begin{tabular}{lcccccc}
\hline \hline \multicolumn{1}{c}{ ATOFMS category } & $r^{2}$ & $r$ & $n$ & $t_{\text {obs }}$ & $t_{\text {crit }}$ & Reject? \\
\hline Percent & & & & & & \\
$\quad$ Crustal-biological & 0.09 & $(-) 0.30$ & 5 & 0.55 & 2.35 & No \\
Salt & 0.41 & $(-) 0.64$ & 5 & 1.44 & 2.35 & No \\
Biomass & 0.32 & $(+) 0.57$ & 5 & 1.19 & 2.35 & No \\
Organic carbon (OC) & 0.11 & $(-) 0.33$ & 5 & 0.61 & 2.35 & No \\
EC and OC-EC mix & 0.14 & $(+) 0.37$ & 5 & 0.70 & 2.35 & No \\
Sulfate-nitrate only & 0.20 & $(-) 0.45$ & 5 & 0.87 & 2.35 & No \\
Number & & & & & & \\
Crustal-biological & 0.00 & $(-) 0.05$ & 5 & 0.10 & 2.35 & No \\
Salt & 0.41 & $(-) 0.64$ & 5 & 1.43 & 2.35 & No \\
Biomass & 0.91 & $(+) 0.95$ & 5 & 5.51 & 2.35 & Yes \\
Organic carbon (OC) & 0.56 & $(+) 0.75$ & 5 & 1.95 & 2.35 & No \\
EC and OC-EC mix & 0.65 & $(+) 0.81$ & 5 & 2.36 & 2.35 & Yes \\
Sulfate-nitrate & 0.35 & $(+) 0.59$ & 5 & 1.27 & 2.35 & No \\
\hline
\end{tabular}

concentration of particles of each type, two correlations with ice crystal concentration were significant: 1) the number concentration of biomass-burning particles and 2) the number concentration of combined EC and ECOC particles. While not shown in a figure, concentrations in both of these categories were highest for the high-ice flight 12 , in agreement with the SP-2 that measured high concentrations of $\mathrm{rBC}$ on this day. Both A-ATOFMS and electron microscopy data indicated that biomassburning particles at cloud level were usually internally mixed with substantial sulfate, indicative of atmospheric aging. Hudson et al. (2004) and Pratt and Prather (2010) determined that biomass-burning particles comprised approximately $1 / 3$ of the particles detected in the North American free troposphere.

Gross et al. (1988) found that woody stems of Prunus contained active ice nucleation sites that were deactivated at higher temperatures than bacterial ice nuclei and were stable when treated with bacterial ice nucleation inhibitors. Petters et al. (2009) showed that biomass-burning particles could be ice nuclei. Their IN efficiencies range from as low as 0 to as high as 1 in every 100 particles, depending on the type of biomass fuel burned; however, the actual compounds responsible for ice nucleation were not directly identified. Sassen and Khvorostyanov (2008) also found evidence for aerosols within boreal biomass smoke nucleating ice at relatively warm temperatures. Insoluble organics and soot both were predicted by Phillips et al. (2008) to produce most of the heterogeneous ice crystals in a modeled biomass-burning-influenced cloud. Further examination of the chemical composition of the ICE-L biomass-burning particles and how they interacted with clouds during flight 12 can be found in Pratt et al. (2010b). 
Surprisingly, no significant correlation with dust and biological particles was found with ice at $-24^{\circ}>T>$ $-29^{\circ} \mathrm{C}$. However, these particles were only found in any substantial percentage on flight 1 . Since the number of clear-air particles detected by the A-ATOFMS on this day was low, the dataset was extended to include clearair periods throughout the flight within the $\theta_{e}$ range, and not only from the beginning of the flight near the clouds shown in Fig. 1a. Thus, the particle percentages used here (based on 33 particles throughout the flight) may not be completely representative of those particles feeding the cloud at warmer temperatures examined in this paper. Pratt et al. (2009a) did find enhanced concentrations of biological and dust aerosols, and relatively high concentrations of ice nuclei, in cloud ice at colder temperatures $\left(-31^{\circ}\right.$ to $\left.-34^{\circ} \mathrm{C}\right)$ sampled toward the end of flight 1 . In that case, ice concentrations were higher (ranging from about 10 to $50 \mathrm{~L}^{-1}$ ) than during the period selected for this paper. Slightly higher concentrations were also observed in a region thought to be impacted by homogeneously nucleated ice falling from above.

\section{3) Single PARTICLE COMPOSITION BY ELECTRON MICROSCOPY}

The CVI inlet was sometimes operated without counterflow gas exiting the tip; in this mode, it functions as a simple subisokinetic inlet for sampling aerosol particles outside of cloud. Sampling was conducted for two to five minutes in clear air upstream of the wave clouds. A twostage round-jet impactor (Rader and Marple 1985) was used downstream of the inlet to separate particles by size. The small particle impactor stage collected 0.11to $0.59-\mu \mathrm{m}$ diameter unit-density particles. This corresponds to 0.08 - to $0.42-\mu \mathrm{m}$ diameter particles for particles of $1.7 \mathrm{~g} \mathrm{~cm}^{-3}$ density at typical sampling pressures of $500 \mathrm{mb}$. The large particle stage collected larger particles up to several microns in size. Particles were impacted onto formvar- and carbon-coated nickel grids and were analyzed individually via scanning transmission electron microscopy (STEM) with energy dispersive analysis of X-rays (the instruments used were a Hitachi S-5500 and a Bruker Quantax 400 with silicon drift X-ray detector). Note that some organics and nitrates volatilize under the vacuum environment of the microscope. At least 50 particles were randomly selected and analyzed per size range per sample. The mean $\theta_{e}$ values of the samples were within the range of $\theta_{e}$ values of interest for the corresponding cloud samples, except for flight 3 for which the only sample available had a mean $\theta_{e}$ about $2.5^{\circ} \mathrm{C}$ lower than the desired mean.

Particles were classified into six primary types including salts (sodium, calcium and magnesium-based), organic carbon, soot (chain aggregates with characteristic spheroid morphology), sulfate, biomass burning (sulfates and organics with potassium), and crustal dust (rich in $\mathrm{Si}$, variable $\mathrm{Na}, \mathrm{Mg}, \mathrm{Al}, \mathrm{K}, \mathrm{Ca}$, and $\mathrm{Fe}$ ) or metals. A "mixed" category was included for particles described by multiple categories-for example, crustal dust internally mixed with salt, or soot mixed with sulfate-because these mixed particle types may be important for their role as both cloud condensation nuclei and heterogeneous ice nuclei. For more information on the classification scheme, see Twohy and Anderson (2008).

Because of the difference in techniques, these categories may give slightly different results than for the A-ATOFMS. In particular, internal mixing of sulfate and organic carbon with soot (detected as elemental carbon) was commonly observed by the A-ATOFMS; in fact, inferred number concentrations of particles containing EC were about a factor of 8 higher than $\mathrm{rBC}$ number concentrations measured by the SP-2, probably because of small inclusions that were below its $0.08-\mu \mathrm{m}$ massequivalent diameter threshold. Although STEM can readily detect large soot particles by their morphology, smaller soot internally mixed with other particles is only apparent with high-resolution imaging, which was not feasible for all particles analyzed. Therefore, soot internally mixed with other particles is underestimated by the technique. For ICE-L, while some mixed and unmixed soot particles were observed via STEM, the numbers were too few to determine significant correlations.

The STEM provides information on the morphology of various nonvolatile particle types (Fig. 5). Two types of organic carbon were observed: round particles that appear to have been liquid upon impaction, as evidenced by satellite rings, and more irregular, apparently solid particles. Although they cannot be positively identified by STEM, the latter type may be biological. This particle type was observed in particularly high quantities on flight 1 , where biological particles were also identified by the A-ATOFMS, as discussed by Pratt et al. (2009a). Particles identified as originating from biomass burning were heterogeneous, exhibiting a variety of different morphologies.

To improve sampling statistics, STEM categorization results for the small and large impactor stage of each sample were combined for comparison with ice concentrations. Results of correlations between STEM categories and ice concentrations are given in Table 5. Ice concentrations are positively correlated with biomassburning aerosols (in terms of percent) and also correlated with biomass-burning, sulfate, organic, and mixed particle types when the number concentration of particles larger than $0.10 \mu \mathrm{m}$ are taken into account. While sulfate itself is not thought to be involved in ice nucleation, biomass-burning aerosols as observed by the 


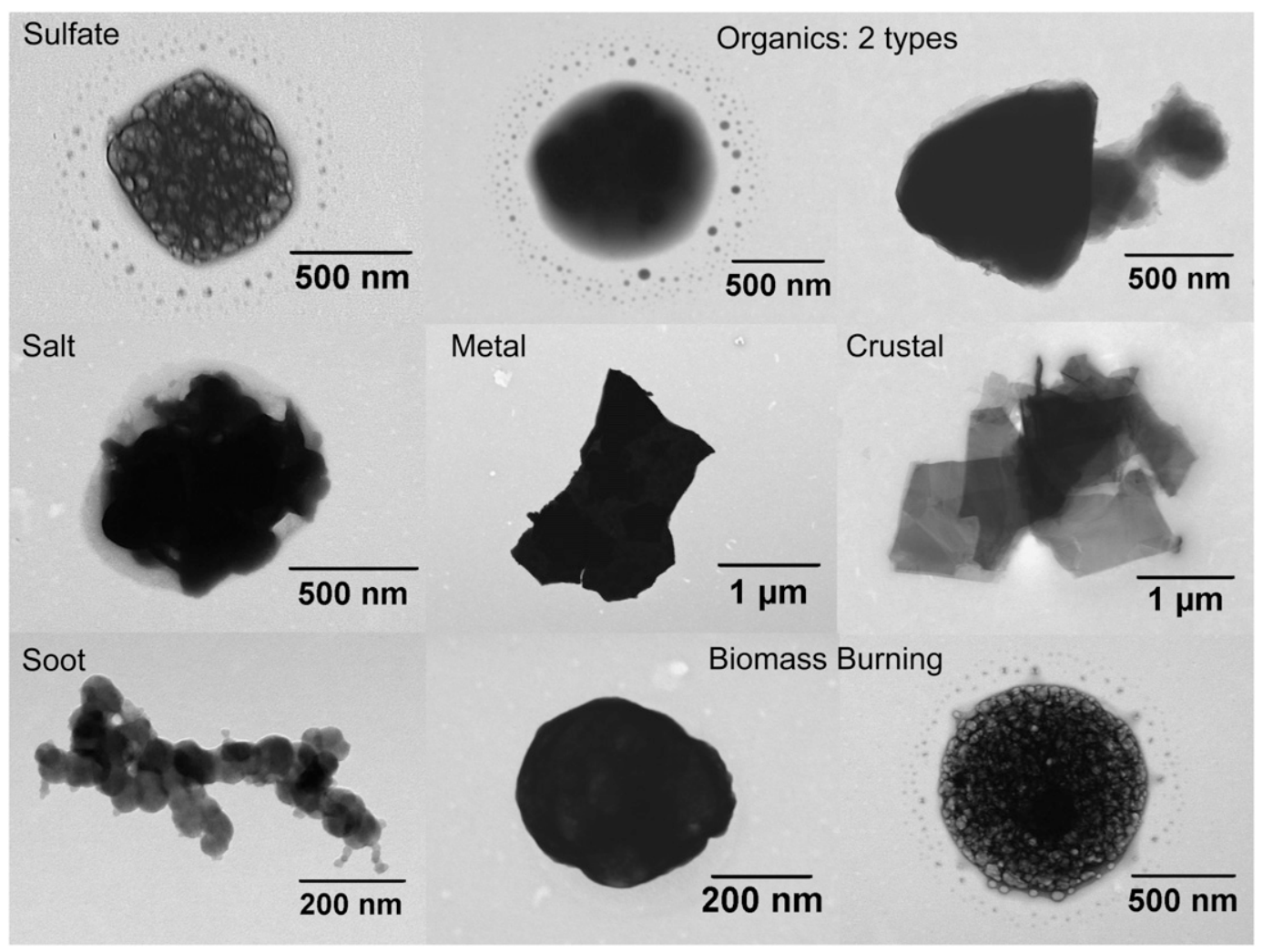

FIG. 5. Examples of different types of particles imaged and analyzed via electron microscopy.

A-ATOFMS and STEM were found to be internally mixed with sulfate, probably due to atmospheric aging. The C-ToF-AMS also showed the highest sulfate mass associated with flight 12 , which was rich in biomassburning particle types. Surprisingly, crustal material and metals measured by the STEM were not significantly correlated with ice concentrations, despite the fact that some types have been observed to nucleate ice in the laboratory and the atmosphere. This may simply be due to high uncertainty in their concentrations, since the number of these particles actually measured was only a few per sample. However, mixed particle types, which contained crustal dust, metals, or soot internally mixed with soluble material like sulfate or other salts, were measured in higher percentages. When combined with UHSAS number concentrations, these mixed particles were found to be positively correlated with ice concentrations.

\section{4) Chemical composition by C-ToF-AMS}

The C-ToF-AMS measured mass concentrations of sulfate, nitrate, total organics, ammonium, and chloride (the latter underestimated because a large fraction is refractory). Mass concentrations measured by the AMS were not multiplied by a collection efficiency because of the lack of an appropriate mass standard on the plane.
Higher-frequency measurements from the C-ToF-AMS were combined into 30-s average mass concentrations that were used for statistical analysis. Most species were near detection limits except for sulfate and total organics. Mass to charge $(\mathrm{m} / \mathrm{z})$ values of $23,39,44,57$, and

TABLE 5. Significance of relationships between STEM aerosol chemistry and ice number concentration in clouds. Top rows are percent relative to other categories; bottom rows are percent multiplied by particles larger than $0.10 \mu \mathrm{m}$ as measured by the UHSAS. Column headings are described in Table 3 footnotes.

\begin{tabular}{lcccccc}
\hline \hline STEM category & $r^{2}$ & $r$ & $n$ & $t_{\text {obs }}$ & $t_{\text {crit }}$ & Reject? \\
\hline Percent & & & & & & \\
$\quad$ Crustal-metals & 0.14 & $(-) 0.37$ & 5 & 0.70 & 2.35 & No \\
Salt & 0.40 & $(-) 0.63$ & 5 & 1.41 & 2.35 & No \\
Biomass & 0.86 & $(+) 0.98$ & 5 & 8.49 & 2.35 & Yes \\
Organic carbon & 0.01 & $(-) 0.10$ & 5 & 0.17 & 2.35 & No \\
Sulfate & 0.12 & $(+) 0.35$ & 5 & 0.64 & 2.35 & No \\
$\quad$ Mixed & 0.06 & $(+) 0.24$ & 5 & 0.42 & 2.35 & No \\
Number & & & & & & \\
$\quad$ Crustal-metals & 0.06 & $(+) 0.24$ & 5 & 0.44 & 2.35 & No \\
$\quad$ Salt & 0.23 & $(-) 0.48$ & 5 & 0.95 & 2.35 & No \\
Biomass & 0.93 & $(+) 0.96$ & 5 & 6.31 & 2.35 & Yes \\
Organic carbon & 0.91 & $(+) 0.95$ & 5 & 5.51 & 2.35 & Yes \\
$\quad$ Sulfate & 0.82 & $(+) 0.91$ & 5 & 3.70 & 2.35 & Yes \\
$\quad$ Mixed & 0.72 & $(+) 0.85$ & 5 & 2.78 & 2.35 & Yes \\
\hline
\end{tabular}


TABLE 6. Significance of relationships between C-ToF-AMS aerosol mass concentrations and ice number concentration in clouds. Column headings are described in Table 3 footnotes.

\begin{tabular}{lcccccc}
\hline \hline AMS Category & $r^{2}$ & $r$ & $n$ & $t_{\text {obs }}$ & $t_{\text {crit }}$ & Reject? \\
\hline Mass & & & & & & \\
$\quad$ Sulfate & 0.86 & $(+) 0.93$ & 5 & 4.29 & 2.35 & Yes \\
Nitrate & 0.35 & $(+) 0.59$ & 5 & 1.27 & 2.35 & No \\
Organic & 0.43 & $(+) 0.66$ & 5 & 1.50 & 2.35 & No \\
Ammonium & 0.27 & $(-) 0.52$ & 5 & 1.05 & 2.35 & No \\
Chloride & 0.31 & $(+) 0.56$ & 5 & 1.16 & 2.35 & No \\
\hline
\end{tabular}

60 (nonquantitative markers for nonrefractory sodium, nonrefractory potassium, oxygenated organic aerosols, hydrocarbon-like organic aerosols, and biomass burning, respectively) were examined but were not meaningful, given the very low mass loadings. Even sulfate exhibited quite low mass concentrations in this region, from a mean of $0.03 \mu \mathrm{g} \mathrm{m}^{-3}$ on flight 1 to a maximum of $0.24 \mu \mathrm{g} \mathrm{m}^{-3}$ on flight 12. Table 6 shows that none of the chemical species measured by the C-ToF-AMS could be significantly tied to ice concentrations, except for sulfate. As discussed previously, the significant correlation with sulfate is likely due to the internal mixing of sulfate with other species in aged particles emitted from biomass burning. Additionally, since sulfate contributed most of the mass, sulfate mass is also likely correlated with the number concentrations of large particles, which in turn are related to ice crystal concentrations.

\section{d. Ice nuclei}

Ice nuclei number concentrations were measured with the Colorado State University continuous flow diffusion chamber (CFDC; Rogers et al. 2001; Eidhammer et al. 2010) under various temperature and water supersaturation conditions. In addition to removing sampling periods that did not fulfill the $\theta_{e}$ criteria used in aerosol analyses or when sampling was in series with the CVI inlet, periods that replicated homogeneous freezing (high supersaturation with respect to water and $T<-35^{\circ} \mathrm{C}$ ) were eliminated from data presented here. The instrument was operated in a liquid water supersaturated mode, so heterogeneous condensation and immersionfreezing processes were simulated. Because the amount of data remaining was relatively small and no discernable or significant variation with temperature alone was observed for the dataset as a whole (DM), IN concentrations were not restricted to processing conditions of $-24^{\circ}>$ $T>-29^{\circ} \mathrm{C}$ (as for the cloud passes); actual processing temperatures included here range from about $-23^{\circ}$ to $-34^{\circ} \mathrm{C}$. Because of low sample volumes and high variability of the IN data, they were first smoothed with a 60-s running average and then averaged for each flight as per the clear-air $\theta_{e}$ screening processes described earlier.

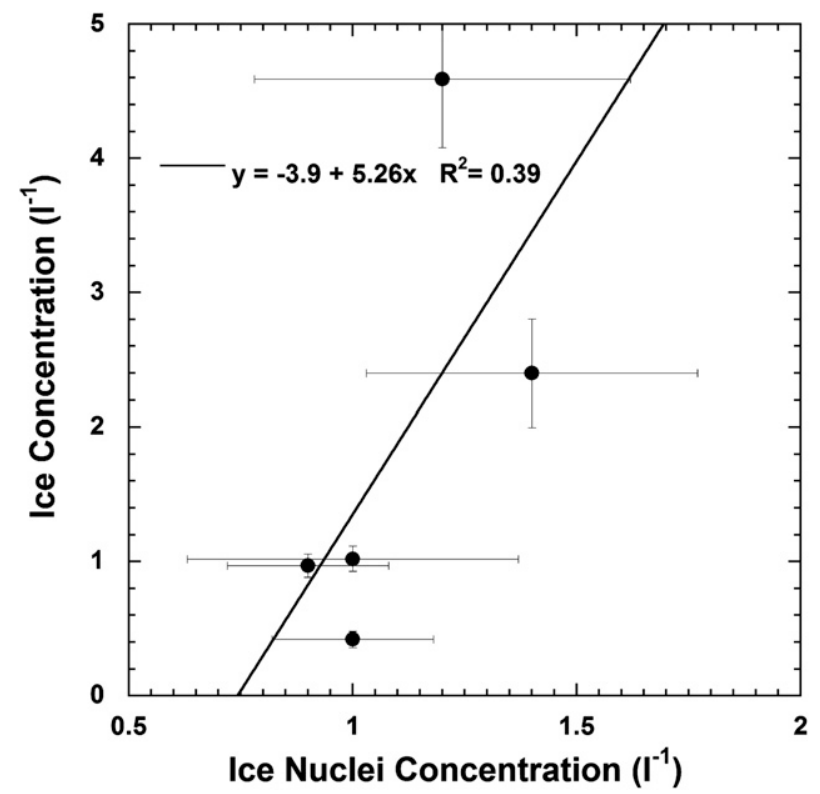

FIG. 6. Relationship between mean IN concentration measured by the CFDC and mean ice concentration in ICE-L wave clouds. For IN concentration, error bars represent the uncertainty based on Poisson statistics; for ice concentration, they represent a $95 \%$ confidence interval for the sample means $[ \pm$ (standard error $\times$ 1.96)]. Measurement uncertainty is estimated at $20 \%$ for ice concentration.

Figure 6 shows the relationship between mean IN concentration and average cloud ice for the selected wave cloud flights and the sampling criteria noted. While the higher IN concentrations do correspond to the flights with higher cloud ice concentrations, all the mean values are quite small. The relationship between IN and ice is not significant at a probability level of 0.05 (Table 3), although it would be significant if the probability level was relaxed to 0.15 . In addition to the small sample size of five cases, several other factors could explain this relatively weak statistical significance.

First, IN concentrations of $\sim 1 \mathrm{~L}^{-1}$ as observed in ICE-L are very low; in fact, the ICE-L values are the lowest measured of eight different airborne field projects throughout the world (DM). This highlights how deficient in IN the air sampled in ICE-L often was. Measurements at these IN levels are extremely challenging, especially for the small sample volumes $\left(1 \mathrm{~L} \mathrm{~min}^{-1}\right.$ sampling rate) possible during the limited time of operation at constant aircraft flight altitudes. In addition, the background counts from frost (determined by alternating periods of sampling with and without a highefficiency filter) in CFDC-type instruments (Richardson et al. 2007) at times equal or exceed these low IN concentrations and limit periods of measurable IN signal. For consideration of the Poisson arrival process that the 
IN measurement represents, the minimum uncertainty in IN concentrations at $1 \mathrm{~L}^{-1}$ depends on the sampling time interval. This uncertainty ranges from 0.2 to $0.4 \mathrm{~L}^{-1}$ for the 7- to 31-min time periods averaged in Fig. 6. Furthermore, a lower detection limit of $0.3 \mathrm{~L}^{-1}$ has been experimentally determined for 5-min sample periods with the CFDC (Prenni et al. 2009). Also, while IN were generally sparse in the ICE-L environment, IN concentrations were quite variable and often detected in discrete layers and regions. These may not be well represented in the final average values or be fully representative of the air actually included in the cloud ice averages, despite our efforts to find comparable $\theta_{e}$ ranges and time periods.

When the IN data were averaged over different time periods not constrained to the $\theta_{e}$ ranges given by the cloud passes in our temperature range $\left(-24^{\circ}>T>-29^{\circ} \mathrm{C}\right)$, higher IN concentrations sometimes resulted. For example, Fig. 7 shows IN concentrations tabulated using all available clear-air data for flights 1 and 3 , plotted against the number concentration of $\mathrm{rBC}$ from the SP-2 as well as against the number concentration larger than $0.5 \mu \mathrm{m}$ from the UHSAS. These two flights are notable because sampling also included two actively burning biomassburning plumes (not directly associated with the wave clouds sampled on those days). When points inside and outside the biomass plumes are included, both relationships are significant at the 0.05 probability level (not shown in tables). The IN number concentrations in the biomass-burning plumes are one to two orders of magnitude higher than in the background atmosphere in this region. However, IN in the plumes alone (e.g., open triangles) do not show a clear positive relationship with refractory black carbon, suggesting that $\mathrm{rBC}$ may not be the primary source, or the only source, of ice nucleating material present. Additionally, it should be cautioned that the fits shown in Fig. 7 apply to the conditions and plumes sampled during ICE-L, and other biomass-burning scenarios may exhibit very different characteristics (Petters et al. 2009).

\section{Summary and discussion}

Ice crystal concentrations in orographic wave clouds at temperatures of $-24^{\circ} \mathrm{C}>T>-29^{\circ} \mathrm{C}$ were compared to aerosol characteristics in nearby clear air with similar equivalent potential temperature values for five flights during ICE-L. Since some of the highest ice concentrations were associated with clouds showing sedimentation from colder temperatures, only data from vertically isolated clouds were included in this analysis to focus on heterogeneously nucleated ice. For these isolated clouds, mean ice concentrations varied by about a factor of 10 from a low on flight 4 (18 Nov 2007) to a high on flight 12

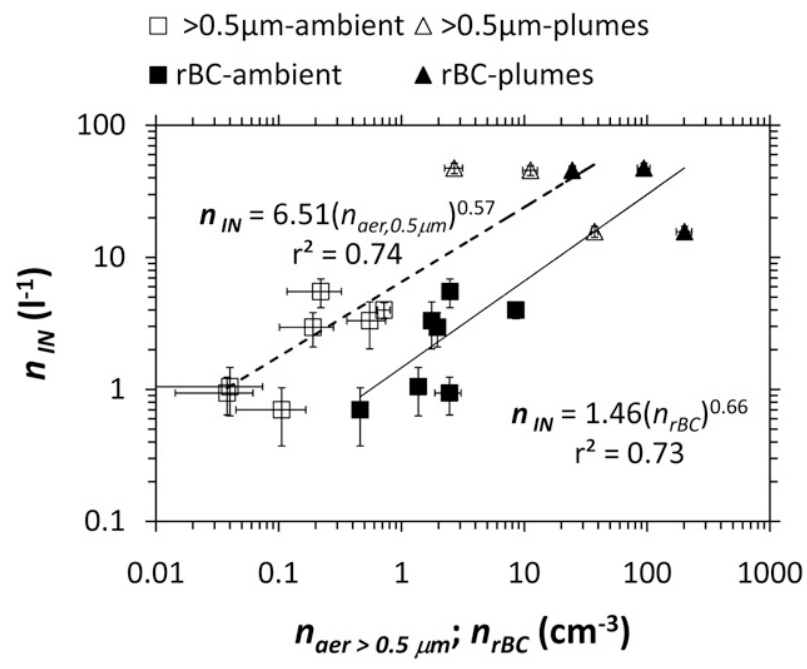

FIG. 7. Relationship between mean aerosol number concentration $>0.5 \mu \mathrm{m}$ (white symbols) and refractory black carbon concentration (total measured by the SP-2, black symbols) vs mean ice nuclei concentration measured by the CFDC. Data shown are those averaged over 3-15-min intervals on flights 1 and 3, where active biomass-burning plumes were sampled (triangles). For particles $>0.5 \mu \mathrm{m}$ and rBC, error bars represent a $95 \%$ confidence interval for the sample means; for IN concentration, they represent the uncertainty based on Poisson statistics. The fit relative to particles larger than $0.1 \mu \mathrm{m}$ (not shown) is $n_{\mathrm{IN}}=0.15\left(n_{\text {aer }, 0.1 \mu \mathrm{m}}\right)^{0.74}$, $\left(r^{2}=0.71\right)$.

(16 Dec 2007). Several significant correlations were observed between clear-air aerosol characteristics and mean ice concentrations. Also, measured clear-air IN concentrations, while low and variable, were of similar magnitude to the measured in-cloud ice concentrations.

Mean ice concentrations were not shown to be related with total aerosol concentration but were positively and significantly correlated with aerosol number concentrations larger than both 0.1 and $0.5 \mu \mathrm{m}$ diameter. In addition, ice concentration was related to refractory black carbon concentration measured by the SP-2 and elemental carbon detected by the A-ATOFMS. Both the A-ATOFMS and the STEM technique showed that the number concentrations of aerosols from biomass burning were positively correlated with ice concentration. Measurements of smoke plumes during ICE-L showed the highest ice nuclei concentrations measured during the study. The STEM technique revealed that mixed particle types containing dust, metals, and soot internally mixed with soluble material were related to ice concentrations.

While correlation does not necessarily signify causation, these relationships observed by several complementary techniques offer strong support for the idea that larger particles emitted by biomass burning play an important role in ice nucleation. Larger particles have also been shown to be correlated with measured ice nuclei 
concentrations (DM). Two likely reasons include the presence of more potential ice nucleating sites in larger particles and the inherent tendency for well-known ice nucleators such as silicates and metals to be large in size, since they are produced mechanically rather than through gas to particle conversion. Our results also show that fresh and aged biomass-burning plumes are apparently a source of ice nuclei. Biomass-burning aerosols are diverse and often contain soot carbon as well as a range of organic and inorganic material. Most prior results show that soot is not a very efficient ice nucleus, and Petters et al. (2009) found that fresh biomass smokes with more soot did not necessarily contain more IN. Therefore, the strong correlations of soot with ice concentrations in our study are not necessarily due to its ice nucleating ability but may be due to its ubiquitous presence in air masses influenced by biomass-burning plumes.

Small amounts of mineral dust or biological particles could have been lofted and transported to our sampling site in conjunction with biomass-burning aerosol (Diehl et al. 2007). However, ice nucleation characteristics of some biomass-burning aerosols reported in Petters et al. (2009) are unlikely to derive from dust, since similar IN efficiencies were observed whether or not the plant material was washed to remove surface particulates prior to burning (M. D. Petters 2009, personal communication). Because of the heterogeneous nature of biomass-burning particles (Fig. 5) and the very small percentage of particles that actually act as ice nuclei, the specific material responsible for ice nucleation cannot be definitely determined by this study. Based on the available evidence, we hypothesize that at least in some cases, it is some insoluble and heat-stable component of the plant material itself. Further studies are clearly needed.

The nucleating efficiency for biomass-burning particles (in terms of number of nuclei per number of particles) may be lower than for more powerful ice nucleators such as dust and some biological material. However, biomassburning particles are often present in greater number concentrations and so still may be important, particularly in locations where the better-known ice nucleators are scarce and where ice concentrations are relatively low, such as we observed in the ICE-L region. Future studies using a CVI to collect and evaporate ice crystals, a CFDC to activate the portion of ice residue that acts as IN, and chemical measurement of those particles could isolate the specific components of biomass-burning aerosols that may be responsible for heterogeneous ice nucleation.

Acknowledgments. We acknowledge the National Science Foundation for a plethora of grants issued to support various aspects of this work: C. Twohy under Grant ATM-0612605, P. DeMott under Grant ATM-0611936, and R. Subramanian and G. Kok under Grant ATM0631919. K. Pratt and K. Prather acknowledge NSF for support of ICE-L (ATM-0650659), A-ATOFMS development (ATM-0321362), and a graduate research fellowship for K.A. Pratt. S. M. Murphy and J. H. Seinfeld acknowledge NSF for support of ICE-L (ATM-0340832) and also NASA for an Earth and Space Sciences Fellowship for S. M. Murphy. Samuel Haimov of the University of Wyoming provided important airborne radar data. Anthony Prenni and Markus Petters are acknowledged for help in collecting CFDC data, Trude Eidhammer for help in both collection and final processing of CFDC data, and Darrel Baumgardner for useful suggestions. Special thanks are due to Rich Cageao, Errol Korn, and Julia Sobolik for CVI support, as well as the entire aircraft crew of the National Center for Atmospheric Research for technical and professional assistance.

\section{REFERENCES}

Andreae, M. O., and A. Gelencsér, 2006: Black carbon or brown carbon? The nature of light-absorbing carbonaceous aerosols. Atmos. Chem. Phys., 6, 3131-3148.

Baker, B. A., and R. P. Lawson, 2006: In situ observations of the microphysical properties of wave, cirrus, and anvil clouds. Part 1: Wave clouds. J. Atmos. Sci., 63, 3160-3185.

Baumgardner, D., R. Subramanian, C. Twohy, J. Stith, and G. Kok, 2008: Scavenging of black carbon by ice crystals over the northern Pacific. Geophys. Res. Lett., 35, L22815, doi:10.1029/ 2008 GL035764.

Bowers, R. M., C. L. Lauber, C. Wiedinmyer, M. Hamady, A. G. Hallar, R. Fall, R. Knight, and N. Fierer, 2009: Characterization of airborne microbial communities at a high-elevation site and their potential to act as atmospheric ice nuclei. Appl. Environ. Microbiol., 75, 5121-5130, doi:10.1128/AEM.00447-09.

Cantrell, W., and A. Heymsfield, 2005: Production of ice in tropospheric clouds: A review. Bull. Amer. Meteor. Soc., 86, 795-807.

Chen, Y., S. M. Kreidenweis, L. M. McInnes, D. C. Rogers, and P. J. DeMott, 1998: Single particle analyses of ice nucleating aerosols in the upper troposphere and lower stratosphere. Geophys. Res. Lett., 25, 1391-1394.

Chýlek, P., and Coauthors, 1996: Black carbon: Atmospheric concentrations and cloud water content measurements over southern Nova Scotia. J. Geophys. Res., 101, 29 105-29 110.

Cooper, W. A., 1974: A possible mechanism for contact nucleation. J. Atmos. Sci., 31, 1832-1837.

— , and G. Vali, 1981: The origin of ice in mountain cap clouds. J. Atmos. Sci., 38, 1244-1259.

Cozic, J., S. Mertes, B. Verheggen, D. J. Cziczo, S. J. Gallavardin, S. Walter, U. Baltensperger, and E. Weingartner, 2008: Black carbon enrichment in atmospheric ice particle residuals observed in lower tropospheric mixed phase clouds. J. Geophys. Res., 113, D15209, doi:10.1029/2007JD009266.

Cziczo, D. J., and Coauthors, 2009: Inadvertent climate modification due to anthropogenic lead. Nat. Geosci., 2, 333-336, doi:10.1038/ ngeo499; Corrigendum 2, 44.

DeMott, P. J., 1990: An exploratory study of ice nucleation by soot aerosols. J. Appl. Meteor., 29, 1072-1079. 
- Y. Chen, S. M. Kreidenweis, D. C. Rogers, and D. E. Sherman, 1999: Ice formation by black carbon particles. Geophys. Res. Lett., 26, 2429-2432.

—, and Coauthors, 2010: Advances toward predicting global ice nuclei distributions. Proc. Natl. Acad. Sci. USA, 107, 11217 11222.

Diehl, K., and S. K. Mitra, 1998: A laboratory study of the effects of a kerosene-burner exhaust on ice nucleation and the evaporation rate of ice crystals. Atmos. Environ., 32, 31453151.

_ - M. Simmel, and S. Wurzler, 2007: Effects of drop freezing on microphysics of an ascending cloud parcel under biomass burning conditions. Atmos. Environ., 41, 303-314.

Durant, A. J., and R. A. Shaw, 2005: Evaporation freezing by contact nucleation inside-out. Geophys. Res. Lett., 32, L20814, doi:10.1029/2005GL024175.

Dymarska, M., B. J. Murray, L. Sun, M. L. Eastwood, D. A. Knopf, and A. K. Bertram, 2006: Deposition ice nucleation on soot at temperatures relevant for the lower troposphere. J. Geophys. Res., 111, D04204, doi:10.1029/2005JD006627.

Eidhammer, T., and Coauthors, 2010: Ice initiation by aerosol particles: Measured and predicted ice nuclei concentrations versus measured ice crystal concentrations in an orographic wave cloud. J. Atmos. Sci., 67, 2417-2436.

Field, P. R., O. Mohler, P. Connolly, M. Kramer, R. Cotton, A. J. Heymsfield, H. Saathoff, and M. Schnaiter, 2006: Some ice nucleation characteristics of Asian and Saharan desert dust. Atmos. Chem. Phys., 6, 1509-1537.

Gierens, K., 2003: On the transition between heterogeneous and homogeneous freezing. Atmos. Chem. Phys., 3, 437-446.

Gorbunov, B., A. Baklanov, N. Kakutkina, H. L. Windsor, and R. Tuomi, 2001: Ice nucleation on soot particles. J. Aerosol Sci., 32, 199-215.

Gross, D. C., E. L. Proebsting, and H. Maccrindle-Zimmerman, 1988: Development, distribution, and characteristics of intrinsic, nonbacterial ice nuclei in Prunus wood. Plant Physiol., 88, 915-922.

Haag, W., and B. Kärcher, 2004: The impact of aerosols and gravity waves on cirrus clouds at midlatitudes. J. Geophys. Res., 109, D12202, doi:10.1029/2004JD004579.

Hallett, J., and S. C. Mossop, 1974: Production of secondary ice particles during the riming process. Nature, 249, 26-28.

Heymsfield, A. J., and L. M. Miloshevich, 1995: Relative humidity and temperature influences on cirrus formation and evolution: Observations from wave clouds and FIRE II. J. Atmos. Sci., 52, 4302-4326.

Hofmann, D. J., R. S. Stone, M. E. Wood, T. Deshler, and J. M. Harris, 1998: An analysis of 25 years of balloonborne aerosol data in search of a signature of the subsonic commercial aircraft fleet. Geophys. Res. Lett., 25, 2433-2436.

Hudson, P. K., and Coauthors, 2004: Biomass-burning particle measurements: Characteristic composition and chemical processing. J. Geophys. Res., 109, D23S27, doi:10.1029/2003JD004398.

Isono, K., M. Komabayasi, and A. Ono, 1959: The nature and origin of ice nuclei in the atmosphere. J. Meteor. Soc. Japan, 37, 211-233.

Jensen, E. J., and Coauthors, 2001: Prevalence of ice supersaturated regions in the upper troposphere: Implications for optically thin ice cloud formation. J. Geophys. Res., 106, 17 253-17 266.

Kärcher, B., O. Mohler, P. J. DeMott, S. Pechtl, and F. Yu, 2007: Insights into the role of soot aerosols in cirrus cloud formation. Atmos. Chem. Phys., 7, 4203-4227.
Korolev, A. V., and G. A. Isaac, 2005: Shattering during sampling by OAPs and HVPS. Part I: Snow particles. J. Atmos. Oceanic Technol., 22, 528-542.

_ J. W. Strapp, and G. A. Isaac, 1998: Evaluation of the accuracy of PMS optical array probes. J. Atmos. Oceanic Technol., 15, 708-720.

Meyers, M. P., P. J. Demott, and W. R. Cotton, 1992: New primary ice-nucleation parameterizations in an explicit cloud model. J. Appl. Meteor., 31, 708-721.

Möhler, O., and Coauthors, 2005: Effect of sulfuric acid coating on heterogeneous ice nucleation by soot aerosol particles. J. Geophys. Res., 110, D11210, doi:10.1029/2004JD005169.

_ , P. J. DeMott, G. Vali, and Z. Levin, 2007: Microbiology and atmospheric processes: The role of biological particles in cloud physics. Biogeosciences, 4, 1059-1071.

Mossop, S., 1976: Production of secondary ice particles during the growth of graupel by riming. Quart. J. Roy. Meteor. Soc., 102, $45-57$.

Murphy, S. M., and Coauthors, 2009: Comprehensive simultaneous shipboard and airborne characterization of exhaust from a modern container ship at sea. Environ. Sci. Technol., 43, 4626-4640.

Noone, K. J., J. A. Ogren, and R. J. Charlson, 1988: Design and calibration of a counterflow virtual impactor for sampling of atmospheric fog and cloud droplets. Aerosol Sci. Technol., 8, 235-244.

Oraltay, R. G., and J. Hallett, 1989: Evaporation and melting of ice crystals: A laboratory study. Atmos. Res., 24, 169-189.

Petters, M. D., and Coauthors, 2009: Ice nuclei emissions from biomass burning. J. Geophys. Res., 114, D07209, doi:10.1029/ 2008JD011532.

Phillips, V. T., P. J. DeMott, and C. Andronache, 2008: An empirical parameterization of heterogeneous ice nucleation for multiple chemical species of aerosol. J. Atmos. Sci., 65, 2757-2783.

Pratt, K. A., and K. A. Prather, 2010: Aircraft measurements of vertical profiles of aerosol mixing states. J. Geophys. Res., 115, D11305, doi:10.1029/2009JD013150.

_ , and Coauthors, 2009a: In-situ detection of biological particles in high altitude dust-influenced ice clouds. Nat. Geosci., 2, 398-401, doi:10.1038/ngeo521.

— , and Coauthors, 2009b: Development and characterization of an aircraft aerosol time-of-flight mass spectrometer. Anal. Chem., 81, 1792-1800.

_ , and Coauthors, 2010a: Observation of playa salts as nuclei in orographic wave clouds. J. Geophys. Res., 115, D15301, doi:10.1029/2009JD013606.

— , and Coauthors, 2010b: In-situ chemical characterization of aged biomass burning aerosols impacting cold wave clouds. J. Atmos. Sci., 67, 2451-2468.

Prenni, A. J., M. D. Petters, A. Faulhaber, C. M. Carrico, P. J. Ziemann, S. M. Kreidenweis, and P. J. DeMott, 2009: Heterogeneous ice nucleation measurements of secondary organic aerosol generated from ozonolysis of alkenes. Geophys. Res. Lett., 36, L06808, doi:10.1029/2008GL036957.

Rader, D. J., and V. A. Marple, 1985: Effect of ultra-Stokesian drag and particle interception on impaction characteristics. Aerosol Sci. Technol., 4, 141-156.

Ramanathan, V., and W. Collins, 1991: Thermodynamic regulation of ocean warming by cirrus clouds deduced from observations of the 1987 El Niño. Nature, 351, 27-32.

Reid, J. S., R. Koppmann, T. F. Eck, and D. P. Eleuterio, 2005: A review of biomass burning emissions. Part II: Intensive physical properties of biomass burning particles. Atmos. Chem. Phys., 5, 799-825. 
Richardson, M. S., and Coauthors, 2007: Measurements of heterogeneous ice nuclei in the western United States in springtime and their relation to aerosol characteristics. J. Geophys. Res., 112, D02209, doi:10.1029/2006JD007500.

Rogers, D. C., and G. Vali, 1987: Ice crystal production by mountain surfaces. J. Climate Appl. Meteor., 26, 1152-1168.

— P. J. DeMott, S. M. Kreidenweis, and Y. Chen, 2001: A continuous-flow diffusion chamber for airborne measurements of ice nuclei. J. Atmos. Oceanic Technol., 18, 725-741.

Sassen, K., and V. I. Khvorostyanov, 2008: Cloud effects from boreal forest fire smoke: Evidence for ice nucleation from polarization lidar data and cloud model simulations. Environ. Res. Lett., 3, 025006, doi:10.1088/1748-9326/3/2/025006.

_ P. J. DeMott, J. M. Prospero, and M. R. Poellot, 2003: Saharan dust storms and indirect aerosol effects on clouds: CRYSTAL-FACE results. Geophys. Res. Lett., 30, 1633, doi:10.1029/2003GL017371.

Schnell, R. C., and G. Vali, 1972: Atmospheric ice nuclei from decomposing vegetation. Nature, 236, 163-165, doi:10.1038/ $236163 \mathrm{a} 0$.

Schwarz, J. P., and Coauthors, 2006: Single-particle measurements of mid latitude black carbon and light-scattering aerosols from the boundary layer to the lower stratosphere. J. Geophys. Res., 111, D16207, doi:10.1029/2006JD007076.

—_, and Coauthors, 2009: Heating rates and surface dimming due to black carbon aerosol absorption associated with a major U.S. city. Geophys. Res. Lett., 36, L15807, doi:10.1029/ 2009GL039213.

Silva, P. J., D.-Y. Liu, C. A. Noble, and K. A. Prather, 1999: Size and chemical characterization of individual particles resulting from biomass burning of local Southern California species. Environ. Sci. Technol., 33, 3068-3076.

Spencer, M. T., and K. A. Prather, 2006: Using ATOFMS to determine OC/EC mass fractions in particles. Aerosol Sci. Technol., 40, 585-594.

Stith, J. L., and Coauthors, 2009: An overview of aircraft observations from the Pacific Dust Experiment campaign. J. Geophys. Res., 114, D05207, doi:10.1029/2008JD010924.

Tabazadeh, A., E. J. Jensen, and O. B. Toon, 1997: A model description for cirrus cloud nucleation from homogeneous freezing of sulfuric acid aerosols. J. Geophys. Res., 102, 23 84523850 .

Twohy, C. H., 1991: Airborne condensation nucleus counter user's guide. NCAR Tech. Note TN-356+EDD, 21 pp.

_ , and M. R. Poellot, 2005: Chemical characteristics of ice residual nuclei in anvil cirrus clouds: Evidence for homogeneous and heterogeneous ice formation. Atmos. Chem. Phys., 5, 2289-2297.

— , and J. R. Anderson, 2008: Droplet nuclei in non-precipitating clouds: Composition and size matter. Environ. Res. Lett., 3, 045002, doi:10.1088/1748-9326/3/4/045002.

_ , A. D. Clarke, S. G. Warren, L. F. Radke, and R. J. Charlson, 1989: Light-absorbing material extracted from cloud droplets and its effect on cloud albedo. J. Geophys. Res., 94, 86238631.

Vardiman, L., 1978: The generation of secondary ice particles in clouds by crystal-crystal collision. J. Atmos. Sci., 35, 2168 2180.

Wallace, J. M., and P. V. Hobbs, 1977: Atmospheric Science: An Introductory Survey. Academic Press, 467 pp. 